\title{
13. Media coverage of the Finnish basic income experiment
}

\author{
Katja Mäkkylä
}

\section{INTRODUCTION}

In 2017-2018 Finland conducted a basic income experiment. The randomly selected experiment group consisted of 2000 unemployed persons between 25 and 58 years. The group received a monthly payment of $€ 560$, unconditionally and without means testing. The main purpose of the experiment was to study the effects of the basic income on employment and well-being. The Finnish basic income experiment was exceptional in many ways and generated interest worldwide. Coverage of the Finnish experiment, in both the Finnish and international media, has been remarkable before, during and after the experiment.

Social experiments cannot be implemented in a laboratory, but rather take place within communities, and their participants are individuals living their everyday lives. Social experiments occur in public; therefore, publicity is one characteristic of such experiments, and it is important to shed light on it. One way to study publicity is to study the media coverage of the issue.

The news media, among other forms of mediated communication, has a significant role in the construction of reality (Couldry and Hepp, 2018). One way the news media can construct reality is by framing how an issue is approached. Frames can be described as 'organizing principles that are socially shared and persistent over time that work symbolically to meaningfully structure the social world' (Reese, 2001: 11).

In this chapter, I explore coverage of the Finnish basic income experiment in both the Finnish and international media. Specifically, I address the research question of how the Finnish and international media have framed the Finnish basic income experiment. To study media coverage, its characteristics, and prevailing perspectives, I used media framing analysis, concentrating on identification of media frames and frame-building.

In this chapter, I first present media framing theory, and the theoretical and conceptual approaches to media frames, and the media framing process. Thereafter, sections on data and methods used in this study are presented. In 
the following sections, I present the findings of the analysis, concentrating first on the Finnish data, then the international data, and then compare the findings of both datasets. In the final section, I summarise the findings and discuss their importance.

\section{MEDIA FRAMES AND MEDIA FRAMING}

Framing has been studied across different disciplines, such as political science, sociology, and media studies. Consequently, there are different approaches, theoretical perspectives, and methods of framing (Hertog and McLeod, 2001). In this chapter, the focus is on approaches that have emerged in media and communication studies.

Communication research has always had a strong focus on the effects of media; however, since the turn of the 20th century, there have been various paradigm changes. In some stages, media effects have been regarded as strong, while in others, the effects have been viewed as more limited. The latest stage, which can be described as 'social constructivism', began in 1980. The social constructivist paradigm emphasises the strong effects of mass media in constructing social reality; however, these effects can be perceived as limited with regard to the interaction between mass media and its audience (McQuail, 2005; Scheufele, 1999). In political communication studies, framing can also be viewed from the perspective of the social construction of meaning (Gamson and Modigliani, 1989).

Agenda-setting and framing are among the most frequently discussed approaches in political communication studies that aim to examine political news content and how it relates to audience knowledge, attitudes, and behaviour (Koch-Baumgarten and Voltmer, 2010). Agenda-setting refers to the belief that mass media defines the issues about which the audience forms opinions, and framing is 'based on the assumption that how an issue is characterized in news reports can have an influence on how it is understood by audiences' (Scheufele and Tewksbury, 2007: 11).

Framing studies have their origins in both sociology and psychology (Pan and Kosicki, 1993). Scheufele (1999) refers to this distinction in defining framing as both a macro-level and a micro-level construct. The focus is on media frames in macro-level analysis, and on individual frames in micro-level analysis, which refer to the frames in individuals' minds that help them process and interpret information. In this study, the focus is on media frames.

Gamson and Modigliani (1987: 143) suggest that the media frame is 'a central organizing idea or story line that provides meaning to an unfolding strip of events.... The frame suggest what the controversy is about, the essence of the issue.' Media frames can also be described as devices that help journalists organise a flood of information (Gitlin, 1980). 
A frequently cited definition of framing is that of Entman (1993), who suggests that media framing consists of selection and salience; framing a news story means to select an aspect to reality and make it salient. Entman suggests that framing accomplishes this by defining problems, diagnosing causes, making moral evaluations, and recommending remedies.

According to Entman (1993), frames can be found in four different locations within the communication process: the communicator, text, receiver, and culture. Based on this classification, framing can be perceived as a process (de Vreese and Lecheler, 2012). Scheufele (1999) presented a framing process model consisting of different stages: frame-building, frame-setting, and the individual effects of framing. Frame-building refers to the internal and external factors that influence the construction of media frames within the newsroom. Internal factors can be considered media routines, such as values or organisational-level questions (Shoemaker and Reese, 1996), or news media's ideological orientation, political or otherwise (Scheufele, 1999). External factors that influence frame-building are the interactions between journalists and elites, interest groups, (Hänggli, 2012) or social movements (Snow and Benford, 1992). When the issue at stake is new for the journalists, it is more likely that elites will succeed in framing the issue in their own way (Scheufele, 1999: 166).

The basic income experiment introduced the concept of social experiments to the wider public in Finland for the first time. Furthermore, the Finnish media had not reported widely on this kind of issue previously, making it difficult to find research on media framing of social experiments. Nevertheless, media framing of basic income was studied previously. Perkiö et al. (2019) conducted a comparative study on media framing of basic income in Canada, Finland and Spain. They compared the frames used in academic literature, activist circles, and country-based debates with the frames used in the media, and discovered that in all three countries, basic income was generally regarded positively in news stories, with the automation of work frame being the most prominent frame. The study also suggested that, in Finnish news articles, the most prominent frame was the labour activation frame, which they explained as being due to the main purpose of the Finnish basic income experiment, which was to test the effects of basic income on work incentives.

In this chapter, the focus of the study is to determine how this new issue the social experiment - is framed in the media. Since the issue had not been covered previously, also of interest is examining the internal and external factors that influence the construction of media frames to identify why the issue is framed in a certain way. 


\section{DATA AND METHOD}

This research used two datasets: one collected from Finnish online news media and the other from international online news media. I examined these two datasets separately, then together by making comparisons between them.

The Finnish dataset comprises 347 articles published between 25 October 2016 and 29 April 2019 from Finnish online newspapers and news sites. ${ }^{1}$ The selected articles were published in national and regional media outlets, tabloids, and media outlets associated with political parties. Many are short news articles, especially those published at the beginning of the experiment in January 2017, although there are also more extensive reports, editorials, columns, and opinion pieces. However, as the majority are news articles, I will use the general term news article here.

The international dataset includes 46 news articles published between 26 August 2016 and 8 December 2019 in online newspapers and news sites from outside of Finland. The selected articles were published in internationally well-known media outlets. The data are limited due to language constraints; consequently, the selected online newspapers mainly cover publications in English. In South Korea, for instance, the Finnish basic income experiment has gained much attention and been covered by the Korean media; however, due to the language barrier, these articles were not included.

Media coverage of the experiment was not spread out equally over this period, but concentrated on certain moments when the experiment's implementation proceeded in a significant way and there were related press releases, such as the beginning of the experiment in January 2017. The midpoint at the beginning of 2018 and the completion of the experiment at the end of 2018 were also moments that received much media coverage. A significant news spike came in February 2019, with the publication of experiment's preliminary results on the effects of basic income on employment and well-being.

The communication and information specialists at Kela helped me compile the datasets by using a media monitoring company to collect online news articles covering the Finnish experiment. In the data selection process, I paid attention to the online news articles' content. The results found via media monitoring were not all about the Finnish basic income experiment, but included some articles on basic income in general, with the Finnish experiment only mentioned. Articles such as these were separated from the data and were not included in the abovementioned number of news articles. The news articles included in the datasets are entirely, or at least partly, about the Finnish experiment.

Both datasets were also limited by the unavailability of some articles due to issues such as changes in web addresses or paywalls. These articles were 
excluded from the data. Television and radio programmes were also not included in the data; therefore, actual media coverage of the experiment was more extensive than was possible to include in this study's data. Nevertheless, the data broadly cover public discussion on the Finnish basic income experiment.

\section{Media Framing Analysis as a Method}

There is a significant variety in methodological approaches to media framing (Matthes and Kohring, 2008). Framing analysis starts by defining the frame and determining the frame type: issue-specific or generic (Matthes, 2009). Semetko and Valkenburg (2000) categorised generic frames used in news articles as economic consequence, conflict, human interest, morality, and responsibility frames. Media framing analysis can be qualitative or quantitative, and the coding process can be conducted either manually or with computer assistance (Matthes, 2009).

Frames can be deductively or inductively determined. The deductive approach uses frames identified and defined in earlier studies. In this approach, it is necessary to clarify the kinds of frames likely to be in news stories, to prevent them from being overlooked during the identification process. In the inductive approach, news stories are analysed carefully and with an open point of view, with the aim of identifying possible frames (Semetko and Valkenburg, 2000).

In the linguistic approach to media framing, the frames are identified in the text by '[analysing] the selection, placement, and structure of specific words and sentences in a text' (Matthes and Kohring, 2008: 260). Pan and Kosicki (1993) developed a linguistic approach, in which they identified the different framing devices used in texts: syntactical structure, script structure, thematic structure, and rhetorical structure.

Syntactical structure refers to the general structure of news stories (headlines, lead, episodes, background and closing). It also refers to choices regarding which experts to interview or quotations to use. Script structure refers to the tendency of journalists to organise a news story by asking who, what, when, where, why and how. Thematic structure refers to a theme that is 'presented or implied, and evidence in the forms of journalists' observations of actions or quotations of a source is presented to support the hypothesis' (Pan and Kosicki, 1993: 60). Rhetorical structure refers to rhetorical choices made within news texts. Metaphors and catchphrases are typical rhetorical devices, but numbers or rates can also be interpreted as such (Pan and Kosicki, 1993).

This was a qualitative study, and coding was conducted manually with the help of the Atlas.ti program. The frames were determined using an abductive approach, which combined inductive and deductive approaches (Layder, 1998; 
Timmermans and Tavory, 2012). Unlike in Pan and Kosicki (1993), the unit of analysis in this study was the article, not the paragraph.

After data collection and selection, I began the analysis process by reviewing the selected news articles to obtain an overview of the data. Next, I applied an inductive approach and analysed a sample of news stories with an open point of view. In this step, I applied Pan and Kosicki's model and searched for the framing devices that signify a frame. The next step was an attempt to identify possible frames. I recognised that it was possible to identify generic frames commonly used in news media, which is why the method used in this study is more abductive than purely inductive or deductive. The generic frames identified were the economic frame, conflict frame, and human-interest frame. These frames created the initial codebook, but the codebook was completed with issue-specific frames: the social experiment frame, identified in both the international and Finnish datasets, and the international attention frame, identified in only the Finnish dataset. This approach allowed me to identify not only the frames commonly used in news articles but also the issue-specific frames, thus creating a more complete description of the issue's framing.

Frames often overlap, making it possible to identify more than one frame in a single news article. The more extensive the news article, the more likely it is that more than one frame can be found. However, one frame usually prevails in an article; therefore, in my analysis, I attempted to identify each article's prevailing frame. This was the most challenging part of my analysis. The economic frame was present in many of the news articles, and in some cases, it was difficult to determine whether it actually was the prevailing frame. Similarly, with the conflict frame, when the article addressed the issue in terms of conflict or disagreement, the subject of the disagreement was usually basic income's economic consequences or measures that should be taken regarding employment.

\section{THE FINNISH BASIC INCOME EXPERIMENT CAN BEEN FRAMED IN MANY WAYS}

In my analysis, I identified five frames in the data, including the economic, conflict, and human-interest frames. In previous studies, these were identified as prevalent news frames, and therefore can be considered generic frames (Neuman et al., 1992; Semetko and Valkenburg, 2000). In addition to these frames which journalists use often, two issue-specific frames were identified in news articles on the Finnish experiment, which I called the social experiment frame and the international attention frame.

In the economic frame, news issues are addressed in terms of the bottom line, profit and loss, and the economic consequences of social and political issues, such as their costs and gains, are the focus. The economic frame is used 
in news stories because the economic consequences of chosen policy options are seen to have significance for the audience (Neuman et al., 1992).

The conflict frame approaches the reported issue from the perspective of disagreement and conflict. The conflict frame is commonly used in news because journalistic practice emphasises telling 'both sides of the story,' and because creating an interesting story with tension requires presenting the good and bad or the right and wrong (Neuman et al., 1992). The presence of conflict is repeatedly referred to as one important news criteria when selecting which events will be news stories (de Vreese and Holli, 2001).

The human-interest frame describes news issues based on how they affect the lives of individuals or groups and by giving the issue a 'human face'. By using stories on an issue's human impact, it is possible to include direct expressions of emotions and evaluative statements in news articles, when journalists tend to avoid making these statements themselves in the name of objectivity (Neuman et al., 1992). With this type of frame, social and political decisions are presented using human stories, cases, and exemplars, which are said to be more effective than statistics presented in news articles (de Vreese, 2014).

The social experiment frame is an issue-specific frame, and it approaches the basic income experiment from the perspective of science and research. With this frame, political decision-making should make use of the results of scientific research, and scientific research should be conducted in such a way that it can be utilised in political decision-making.

The international attention frame is also an issue-specific frame, and was identified only in the Finnish dataset. With this frame, the basic income experiment is treated in terms of international media attention. Journalists describe international reporting on the Finnish experiment and the observations and representations of Finland and the Finnish people in the international media.

\section{Frames in the Finnish Media}

The economic frame was the most prominent frame in the Finnish data. The economic frame could be identified in many news articles, even when it was not the prevailing frame. The Finnish basic income experiment is an issue that concerns citizens' livelihood and income distribution in society; therefore, it is frequently framed in economic terms. When the Finnish media places the basic income experiment within the economic frame, the focus is on employment and work incentives. Therefore, the employment frame could be considered a sub-frame of the economic frame. This framing is essentially influenced by the experiment's main purpose, which was to understand how receiving a basic income affects participants' financial and employment status. The experi- 
ment's participants were randomly selected unemployed persons who received unemployment benefits from Kela in November 2016.

The basic income experiment promises to provide knowledge on how to combine low and occasional income with unemployment benefits. The weakness of our current social security system is that it is seen as making citizens passive. Finding a job, even when it is small and low-paid, should always be incentivised. The aim of the experiment is to look for answers to the question: in what situations do the unemployed have incentives to find a job? (Keskisuomalainen, 9 January 2017) ${ }^{2}$

The news media's political or ideological orientation also influences framing. Thus, the economic frame is especially prominent in business- and finance-oriented news media.

The conflict frame was identified in Finnish news articles that covered the basic income experiment from the perspectives of different political parties. Thus, disagreements and confrontations are described mostly between different political parties and their opinions. Basic income is unconditional and without work requirements by definition; however, most Finnish political parties support models in which income is conditional and recipients are obligated to search for work or be active in other ways. This is why the basic income experiment has been seen as a controversial issue.

The conflict frame was prominent in news media closely associated with political parties, which have written a lot on basic income and the basic income experiment. In their reporting, the party newspapers mostly aligned with their political party on social security, basic income, and the basic income experiment. The National Coalition Party and Christian Democrats also discussed Universal Credit, an alternative model to basic income previously introduced in the United Kingdom, which these parties believed could be successful in Finland.

However, some political parties also had internal disagreements on which basic income model they wanted to support. Therefore, conflicts appear not only between but also within political parties. These conflicts were described in the media especially in 2018 and at the beginning of 2019, before the parliamentary election in which social security reform was a central topic.

The disagreement between conditionality and unconditionality was again raised in the Finnish media at the beginning of the experiment's second year. In January 2018, the 'activation model' for unemployed persons came into effect, which included an obligation that people either actively search for work or participate in employment services to receive unemployment benefits (Kyyrä et al., 2019). Since the basic income experiment ran simultaneously with the activation model, they were usually presented in contrast to each other. 
It was also possible to identify critical voices other than those of political parties. Some high-profile civil servants also expressed their opinions on the basic income experiment in Finland.

The government launched the basic income experiment in January, and it has been closely followed worldwide. Now, the Chief Secretary of the Ministry of Finance, Martti Hetemäki, in his latest column has practically rejected the basic income that has been tested in the experiment. (Helsingin Sanomat, 19 July 2017)

In the Finnish media, the human-interest frame was prominent, especially in the national tabloids, which are the most widely read newspapers in Finland (Kansallinen Mediatutkimus, 2019). The human-interest frame described the Finnish experiment mainly from the perspective of its participants. When using this type of framing, participants' stories were mainly positive, and they often expressed that they felt lucky to be chosen as part of the experiment.

Mr. Heikkinen, who has been unemployed for more than four years, stated he feels he is lucky, because he was one of the 2000 unemployed people who were randomly selected to take part in the basic income experiment. During the two-year experiment, Mr. Heikkinen will receive 560 euros, tax-free, in his account each month. (Iltalehti, 28 September 2017)

In the interviews with participants, the main considerations were their employment and livelihood; however, the experiment's effects on well-being were also highlighted. Some participants reported that their stress decreased after they started to receive a basic income. However, there were participants who reported that receiving basic income had no impact on their lives, or that it made things more difficult for them.

The same focus on the effects of basic income on well-being was reflected in the news articles which reported the results of a survey study conducted as a part of the evaluation study. In the survey, individuals from both the treatment and control groups were asked about their health and well-being, as well as their trust in other people and in institutions in society and their confidence in their own future and in their ability to influence things. The survey results showed that, compared with the members of the control group, those in the treatment group (i.e. the experiment's participants) felt less stressed and more confident (see Chapters 7, 8 and 10 in this volume).

Stories on participants appeared, especially in tabloids and national media. However, only a small group of participants appeared in the media. Among the 2000 participants, 24 provided interviews to different media outlets. This number was determined based on the number of individuals who were named in the news articles of the database. In the evaluation study the effects of the basic income experiment were studied through a phone survey (see Chapter 
5 in this volume). In the survey, the participants in the experiment group and in the control group were also asked if they have given interviews to media regarding the basic income. A similar number of participants in the experiment group stated they had granted interviews to the media (see Table 13A.1 in the appendix).

Those who responded to requests for interviews by media outlets may not necessarily be a 'representative sample' of the experimental group. Although only a small number of participants shared their experiences and opinions in the media, their stories were widely covered, and thus contributed to how the experiment was portrayed to the public.

The social experiment frame could also be identified in the Finnish data. In this frame, the experiment is significant because it not only generates knowledge on basic income but also on incentive traps and the well-being of the unemployed. Accordingly, political decision-makers can apply this knowledge when planning social security reform. However, this framing was typically used when social policy or economics experts evaluate or criticise the experiment's implementation. Many experts agreed that social experiments are necessary, but repeatedly highlighted flaws in the basic income experiment. Some experts also suggested different models for the experiment. With this frame, the consensus was about the necessity of experiments, with more experiments on different issues suggested.

Let us hope that the experiment gives practical knowledge on the questions hanging in the air and measures will be taken based on this knowledge. The model is barely ready, and there may be need for more experiments. Now, we finally get started. (Kaleva, 6 January 2017)

This frame was influenced by the communication strategies of the Finnish Social Security Institution (Kela), which implemented the experiment, and the Ministry of Social Affairs and Health, as a representative of public administration. Both actively communicated details about the experiment in press releases and on their social media channels at different stages of the experiment. Their press releases sent to media outlets were well received, and the reporting on the experiment was based largely on these press releases, repeating their viewpoints and what they chose to emphasise. Thus, those who planned and implemented the experiment were also able to influence the content and direction of public discussion on the topic.

In addition to these frames, the international attention frame was identified in the Finnish dataset. Finnish tabloids in particular reported on the experiment in terms of the international attention it gained. These articles usually summa- 
rised international media coverage on the issue and pointed out that Finland and the Finnish people have been noticed worldwide.

Among others, the BBC, the Italian Rail, the Swiss Radio Tèlévision Suisse, and the Japanese media outlets Asahi Shimbun and The Nikkei have contacted Iltalehti [Finnish tabloid] in order to ask for the contact information of the participants of the experiment. (Iltalehti, 28 September 2017)

In Finland, attention from international media outlets is considered exceptional and desirable, probably because relatively little is known internationally about Finland and it is a small player in global politics. The Finnish Ministry of Foreign Affairs and its Unit for Country Image, which works to enhance Finland's positive image, also noticed that the Finnish experiment gained a lot of attention worldwide. Consequently, they used the experiment to promote the country by presenting it as a typical Finnish social innovation. ${ }^{3}$

\section{Frames in the International Media}

The economic frame was also the most prominent frame in the international dataset. As with in the Finnish media, this frame's prominence can be explained by the main purpose of the Finnish experiment being to understand how receiving a basic income affects participants' financial and employment status.

The international media often framed the Finnish experiment from a broader economic perspective. The background information provided in this framing typically focuses on economic challenges, such as the economic recession Finland has faced in recent years. In explaining the economic challenges, some articles mention the economic sanctions directed towards Russia - an important trading partner of Finland - due to the Ukrainian crisis. The collapse of Nokia's mobile phone business and its influence on unemployment in Finland was also noted. Thus, the recession and increased unemployment were suggested as the motivation behind the basic income experiment.

The Finnish economy has struggled for the last decade due to a string of problems, including high labour costs, a decline of Nokia's former mobile phone business and recession in neighbouring Russia, a major trade partner. (Reuters, 18 January 2017)

The economic frame in the international media was often influenced by the orientation of the media outlets. Many of the news articles in the dataset were published in business and financial news outlets, such as Financial Times, Forbes and Business Insider.

The human-interest frame could also be identified in the international media. It focuses on the personal stories of the experiment's participants. With 
this framing, a voice was given to people who had experienced periods of unemployment and struggled with the bureaucracy of social security. Without exception, the interviewees had a positive attitude towards basic income and the experiment. They described how participation in the experiment changed their lives, as well as sharing their opinions on the social security system and its flaws and suggestions on how to improve it.

Ideas flow out of Järvinen as easily as water from a tap, yet he could exercise none of his initiative for fear of arousing bureaucratic scrutiny. (The Guardian, 1 November 2017)

International media outlets also applied conflict frames. When reporting on the Finnish experiment, a juxtaposition was often created between supporters and opponents of both the concept of basic income and the experiment itself. Notably, the supporters of basic income did not always support the experiment, but rather adopted a critical approach to it. They usually criticised the purpose of the experiment, initiated by the centre-right government of Prime Minister Juha Sipilä, or pointed toward what they viewed to be inadequate implementation. Further, international media outlets often portrayed trade union representatives as the main critics of basic income and the experiment, as they usually had reserved or negative attitudes towards both.

Finnish politics is intricate: the Centre party, Greens and a far-left party back the study. So does a libertarian wing of the conservatives, hoping to pare the welfare state. Sceptics include traditional conservatives, many Social Democrats and big unions. (The Economist, 24 June 2017)

The social experiment frame could also be identified in the international media dataset. This frame is an issue-specific frame with a focus on the future, and treats political decision-making from the point of view of how we can construct a better future and more functional society. The vision of the future is often one in which automation and robotisation have replaced human labour, and basic income is needed to secure citizens' livelihood. This framing sees the use of scientific research in political decision-making to be of primary importance. In this frame, government employees and researchers did not present opinions on whether basic income should be introduced, but merely stated that the main purpose of the experiment was to generate knowledge for social security reform.

Finland's centre-right government started the trial under a new framework that allows it to try various social policies through randomised tests. Mr. Kanerva says the goal is to make Finland 'the most innovative and experiment-friendly country by 2020'. (The Financial Times, 28 January 2018) 
The Finnish Social Security Institution (Kela) and the Ministry of Health and Social Affairs influenced the use of this frame. Along with the enormous international attention on the experiment, press releases from Kela and the Ministry of Social Affairs and Health were also published in English and, in February 2019, press releases were published in German, French, Russian and Italian. The journalists at international media outlets also interviewed the researchers and authorities involved in planning and implementing the experiment.

\section{Differences between the Frames in the Finnish and International Media}

When comparing the framing in the Finnish and international media, the different premises in the collected data must be taken into account. First, the international media dataset consists of publications from large media outlets, whereas the Finnish data also include smaller regional newspapers and political party newspapers. Second, in many countries, the media has strong political and ideological dependence, and this naturally had an effect on how the basic income and the Finnish experiment were approached and framed. Still, when comparing the reporting on the issue in the Finnish and international media, it is possible to perceive differences.

In the international media, the issue was covered in terms of economics, employment, and the social security system. Participants' personal stories were often highlighted. These characteristics also appeared in the Finnish media, with mostly the same interviewees, experts and participants.

The differences in framing between the Finnish and international media can be identified in the social experiment frame. The international media represented the experiment and its results as significant to the changes in working life and explored its consequences, whereas the Finnish media approached the issue from the perspective of social security reform. In the Finnish media, basic income is not seen as something that could replace salaries that have disappeared due to automation and robotisation of work, but rather as a potential model to consider when planning and implementing social security reform.

The conflict frame was more frequent in the Finnish media than in the international media. The basic income experiment and the concept of basic income itself lead to strong positions in Finnish political parties. Many Finnish political parties have suggested alternative models to basic income. In international media, conflicts and disagreements were not described in such detail, and alternative models were not presented.

\section{DISCUSSION ON FRAMES AND CONCLUSIONS}

The Finnish basic income experiment has been framed as an economic issue, as an issue that creates conflict and disagreement, as a human-interest issue, as 
a social experiment, and as an issue that draws international attention. As suggested above, media frames contribute to the construction of reality. What kind of reality do these media frames construct? Why are these frames selected or, in other words, why does the media choose these perspectives when reporting on the Finnish experiment?

The Finnish and international media have most commonly framed the Finnish experiment in terms of the economy and employment. The focus is on the effects of basic income on employment, and, more specifically, on work incentives. The purpose of the Finnish basic income experiment was to explore whether basic income could incentivise participants to work or start a business, and this purpose seems to have influenced media framing as well. The prevalence of this framing in media coverage highlights the potential economic consequences of basic income and provides less attention to other possible effects basic income could have on recipients. This finding is in line with Perkiö et al. (2019), who compared the frames used in academic literature to those used in the media, and found that in the Finnish media, the labour activation frame was the most prominent.

In the conflict frame, the focus was on the comments and proposals of different political parties regarding the experiment and basic income. In Finland, basic income is seen as an alternative alongside other social security models, and the political parties who support basic income have offered definitions and plans on how to implement a functioning basic income model, or another similar model. With this framing, the proposals of different political parties and actors are usually tied to questions on employment and incentive traps. Only the Left Party and the Green League offer basic income as a solution to increase individuals' liberty, autonomy and well-being. Thus, the conflict frame not only constructs reality full of tension and juxtapositions but also, in 'telling both sides of the story', offers different solutions to questions on social policy.

When the Finnish experiment is placed in the human-interest frame, the focus is on individuals and their experiences and feelings. With this framing, the experiment's participants and unemployed individuals were able to provide an alternative voice to the specialists and authorities who were repeatedly interviewed in the articles. In this frame, basic income's effects on participants' well-being were strongly emphasised. The same focus on how basic income affects well-being was reflected in the reporting of the survey data in which the experiment's participants were asked about their health and well-being as well as their trust in people and in institutions and confidence in their own future (Chapters 7, 8 and 10).

The social experiment frame emphasises the role of scientific research in policymaking. With this framing, the basic income experiment was described as a research project to produce knowledge on basic income and its effects. In 
this frame, specialists and authorities did not take a stand for or against basic income. This presents the experiment as a value-free project or a tool for generating knowledge to influence policymaking.

The international attention frame sheds light on the significant international attention the Finnish experiment gained. This framing presented the Finnish experiment as an issue that draws mainly positive attention to Finland. The experiment was seen as unique, and Finland was viewed as a country that was leading the way in implementing social experiments. Mainly positive international attention towards the Finnish experiment in general contributed to the construction of a positive image of the country.

Focusing on frame-building can also help to improve understanding of the motivations behind news frames and the framing process. As suggested earlier in this chapter, frame-building is influenced by both internal and external factors (Scheufele, 1999).

Internal factors, such as news values or editorial processes, are especially reflected in the use of generic frames. Journalists apply the economic frame because the economic consequences of the issue - in this case, the basic income experiment in Finland - could have significance for members of the public. The employment issues strongly connected to the Finnish experiment are also important issues to the public. Use of the conflict frame reflects the journalistic tradition of telling both sides of the story. In the case of the Finnish experiment, political parties and authorities who did not support the idea of basic income or the tested basic income model usually told the 'other side of the story'. Journalists also applied the human-interest frame that enabled them to explain the abstract experiment in more concrete terms for a larger public. The human-interest frame makes a news story more appealing by highlighting individuals' experiences to evoke both emotions and opinions. Internal factors can also include the orientation of a particular news outlet, such as a political orientation, which was reflected in the issue's framing in Finnish news media associated with political parties. In addition, in both the Finnish and international datasets, the economic frame was prominent when the issue was presented in business- and finance-oriented news media.

The most influential external factor in the frame-building of the Finnish experiment has been the Social Security Institution (Kela) and the Ministry of Social Affairs and Health. Their press releases and social media updates were widely noticed, and influenced the way many media outlets framed the issue. Kela and the Ministry have framed the basic income experiment from the perspective of scientific research. With this framing, the basic income experiment and its results are primarily presented as tools for gathering knowledge for social security reform. Other external factors influencing frame-building are political parties, single politicians, public servants, or basic-income activists, who have offered their own framing to media outlets. With a relatively new 
issue, it is highly likely that political parties and other elites will influence how it is framed. The basic income experiment introduced the concept of social experiments for the first time to the wider public in Finland. Therefore, the media's reporting on the Finnish experiment mainly followed the framing suggested by Kela and the Ministry.

The limitations that apply to this study are regarding the comparison between two different datasets. The Finnish dataset is larger and it covers smaller regional news media and media outlets associated with political parties, while the international dataset consists of internationally well-known media outlets. Smaller international media outlets, which were not included in the dataset, may have reported on the Finnish experiment in different ways.

This study focused on media frames and the factors that influence media-framing. Further studies could be conducted on the effects of media frames on the audience (i.e. how individuals in the audience interpret media frames). Thus, it would be possible to observe how media coverage of the Finnish basic income experiment has shaped the idea of basic income or the idea of social experiments among audience members. Finally, as public opinion is based on the audience's ideas and perspectives, public opinion may be the determining factor in the future of basic income and social experiments.

\section{NOTES}

1. A list of the online newspapers and news sites included in this study can be requested from the author.

2. The original language of the quotations of the Finnish news articles is Finnish. The author of this article has translated the quotations into English.

3. The Finnish Basic Income-Experiment 2017-2018. Retrieved from: https:// toolbox.finland.fi/life-society/finlands-basic-income-experiment-2017-2018/

\section{REFERENCES}

Couldry, N., and Hepp, A. (2018), The Mediated Construction of Reality, Cambridge: Polity Press.

De Vreese, C. H. (2014), 'Mediatization of news: the role of journalistic framing', in Esser, F. and Strömbäck, J. (eds), Mediatization of Politics: Understanding the Transformation of Western Democracies, London: Palgrave Macmillan, pp. 137-55.

De Vreese, C. H., and Lecheler, S. (2012), 'News framing research: an overview and new developments', in Semetko, H. and Scammel, M. (eds), The SAGE Handbook of Political Communication, London: Sage, pp. 292-306.

De Vreese, J. P., and Holli, A. C. H. (2001), 'Framing politics at the launch of the euro: A cross-national comparative study of frames in the news', Political Communication, 18(2), 107-22.

Entman, R. M. (1993), 'Framing: Toward clarification of a fractured paradigm', Journal of Communication, 43(4), 51-8. 
Finland's Basic Income Experiment 2017-2018, website, available at https://toolbox .finland.fi/life-society/finlands-basic-income-experiment-2017-2018/ (accessed 16 December 2020).

Gamson, W., and Modigliani, A. (1987), 'The changing culture of affirmative action', in Braungart, R. G. and Braungart, M. M. (eds), Research in Political Sociology Vol. 3, Greenwich: CT: JAI Press, pp. 137-77.

Gamson, W. A., and Modigliani, A. (1989), 'Media discourse and public opinion on nuclear power: A constructionist approach', American Journal of Sociology, 95(1), $1-37$.

Gitlin, T. (1980), The Whole World is Watching: Mass Media in the Making \& Unmaking of the New Left, Berkeley: University of California Press.

Hertog, J. K., and McLeod, D. M. (2001), 'A multiperspectival approach to framing analysis: a field guide', in Reese, S. D., Gandy, O. H., and Grant, A. E. (eds), Framing Public Life: Perspectives of Media and Our Understanding of the Social World, Mahwah NJ: Erlbaum, pp. 139-61.

Hänggli, R. (2012), 'Key factors in frame building: How strategic political actors shape news media coverage', The American Behavioral Scientist, 56(3), 300-17.

Kansallinen Mediatutkimus (2019), 'Lukijamäärät ja kokonaistavoittavuudet' [The National Media Research 2019, The Number of Readers and the Total Coverage], available at https://mediaauditfinland.fi/wp-content/uploads/2020/03/ Lukijamaarat2019.pdf (accessed 16 December 2020).

Koch-Baumgarten, S., and Voltmer, K. (2010), 'Public policy and the mass media: the interplay of mass communication and political decision making', in Koch-Baumgarten, S. and Voltmer, K. (eds), Public Policy and the Mass Media (Vol. 66), London: Routledge/ECPR.

Kyyrä, T., Naumanen, P., Pesola, H., Uusitalo, R., and Ylikännö, M. (2019), Aktiivimallin vaikutukset työttömiin ja TE-toimistojen toimintaan [The Impact of the Activation Model on the Unemployed and the Operations of TE Offices], Helsinki: VATT Institute for Economic Research, VATT Tutkimukset 189.

Layder, D. (1998), Sociological Practice: Linking Theory and Social Research, London: SAGE Publications.

Matthes, J. (2009), 'What's in a frame? A content analysis of media framing studies in the world's leading communication journals, 1990-2005', Journalism \& Mass Communication Quarterly, 86(2), 349-67.

Matthes, J., and Kohring, M. (2008), 'The content analysis of media frames: toward improving reliability and validity', Journal of Communication, 58(2), 258-79.

McQuail, D. (2005), Mass Communication Theory (5th ed.), London: Sage.

Neuman, W. R., Crigler, A. N., and Just, M. R. (1992), Common Knowledge: News and the Construction of Political Meaning, Chicago: University of Chicago Press.

Pan, Z., and Kosicki, G. M. (1993), 'Framing analysis: an approach to news discourse', Political Communication, 10(1), 55-75.

Perkiö, J., Rincon, L. and Van Draanen, J. (2019), 'Framing basic income: comparing media framing of basic income in Canada, Finland, and Spain', in Torry, M. (ed.), The Palgrave International Handbook of Basic Income. Exploring the Basic Income Guarantee, Cham: Palgrave Macmillan, pp. 233-51.

Reese, S. (2001), 'Prologue - framing public life: a bridging model for media research', in Reese, S., Gandy, O., and Grant, A. (eds), Framing Public Life, Mahwah, NJ: Erlbaum, pp. 7-31.

Scheufele, D. A. (1999), 'Framing as a theory of media effects', Journal of Communication, 49(1), 103-22. 
Scheufele, D. A., and Tewksbury, D. (2007), 'Framing, agenda setting, and priming: the evolution of three media effects models', Journal of Communication, 57(1), 9-20.

Semetko, H. A., and Valkenburg, P. M. (2000), 'Framing European politics: a content analysis of press and television news', Journal of Communication, 50(2), 93-109.

Shoemaker, P., and Reese, S. (1996), Mediating the Message: Theories of Influences on Mass Media Content (2nd ed.), White Plains: Longman.

Snow, D. A., and Benford, R. D. (1992), 'Master frames and cycles of protest', in Morris, A. D. and Mueller, C. M. (eds), Frontiers in Social Movement Theory, New Haven, CT: Yale University Press, pp. 133-55.

Timmermans, S. and Tavory, I. (2012), 'Theory construction in qualitative research: from grounded theory to abductive analysis', Sociological Theory, 30(3), 167-86.

\section{APPENDIX}

Table 13A.1 The number and percentages of persons interviewed in the media regarding the basic income experiment, according to a phone survey

\begin{tabular}{lrrrrrr}
\hline $\begin{array}{l}\text { The number of times } \\
\text { the person was } \\
\text { interviewed }\end{array}$ & \multicolumn{2}{c}{ Experiment group } & \multicolumn{2}{c}{ Control group } & \multicolumn{2}{c}{ All } \\
\hline & $n$ & $\%$ & $n$ & $\%$ & $n$ & $\%$ \\
\hline None & 430 & 94.5 & 814 & 98.5 & 1244 & 97.1 \\
1-5 times & 17 & 3.7 & 11 & 1.3 & 28 & 2.2 \\
$5-10$ times & 3 & 0.7 & 1 & 0.1 & 4 & 0.3 \\
More than 10 times & 3 & 0.7 & 0 & 0.0 & 3 & 0.2 \\
Unsure & 2 & 0.4 & 0 & 0.0 & 2 & 0.2 \\
In total & 455 & 100.0 & 826 & 100.0 & 1281 & 100.0 \\
\hline
\end{tabular}

